\title{
Rethinking Measures of Psychological Agency: A study on the urban fringe of Bamako
}

\begin{abstract}
Attempts to measure psychological agency have drawn on social psychology scholarship. Nonetheless, it is well documented that the Euro/American psychology paradigm is challenged by its tendency to universalise its theories. This raises a challenge for development scholars trying to measure the psychological domain; especially with regards to understanding what the psychological domain may mean to people outside the Western liberal tradition. We examine the use of theoretical measures of psychological agency against local concepts of psychological agency from a neighbourhood on the urban fringe of Bamako. We conclude that there is no clear association between local and theoretical measures of psychological agency and therefore there is a need to include local and theoretical measures in the study of agency.
\end{abstract}

Keywords: Empowerment, autonomy, psychological measure, mixed methods, Mali.

JEL Classification: B54, O15, O53. 


\section{Introduction}

This paper examines the measurement of agency and empowerment, particularly regarding the psychological domain. Human agency is a contested concept in the social sciences (Long, 2001). Agency is contested for its temporal focus (Emirbabyer and Mische, 1998), its level of analysis (Stewart, 2005), its instrumental and intrinsic properties (Sen and Dreze, 2002, Alkire, 2007), its paradoxically oppressive and emancipatory capability (Foucault, 1977; 1982, Butler 1997) and, its dialectic relationship with structure (Giddens, 1984, Bourdieu 1977). Increasingly, intentional and purposeful agency is important in the international development context as a way in which agents’ negotiate their lives (Sen, 1999; Nussbaum, 2001; Alkire, 2008; Kabeer, 1999; Dreze and Sen, 1995; Batiwala, 2007; Chambers, 1997; Narayan et al. 2009, Alsop et al. 2006). For example, in his work on the Capability Approach, Sen has defined the term 'agency' as purposive, and argued for agency to be at the heart of all processes of development and social change (Sen, 1999). Within the Capability Approach, Sen explains the usefulness of expanding human freedoms not just through opportunities or the 'substantive freedoms' that the members of a society enjoy, but also through empowerment and agency, which Sen calls 'process freedoms' (Sen, 1999). Sen considers empowerment being linked to purposeful agency, where both are essential in creating social change, enhancing "the ability of people to help themselves and also to influence the world, these matters are central to the process of development” (Sen , 1999: 18).

Purposeful agency can be further expanded upon through the literature on empowerment. Definitions of empowerment are generally multidimensional and can include the following domains: firstly empowerment as a favourable opportunity structure (Alsop et al, 2006; Narayan et al. 2009), secondly empowerment as choice and decision-making ability (Kabeer, 2003; Kabeer, 1999; Olney and Salomone, 1992), and thirdly empowerment as relations of power (Wee et al. 2008, Batiwala 2007). In our perspective, a comprehensive and integrated view of agency and empowerment also includes psychological aspects (Klein, 2014; Kabeer 1999; Rowlands, 1997; Narayan et al., 2009). For this reason in this paper we propose a fourth domain that we refer as to psychological empowerment. Clearly, it is difficult to draw a definitive line between these four domains of empowerment, as each definition is not exclusive from the other 
domains. Nonetheless, the importance of the differing dimensions of empowerment becomes clear in the way certain dimensions are measured. We will now briefly outline possible issues arising from the measurement of these domains of empowerment.

Defining empowerment as a favourable opportunity structure would suggest that agency can influence opportunity structure and vice versa, which results in degrees of empowerment or disempowerment (Alsop et al. 2006). A possible issue with defining empowerment in this way is that complexity can be overlooked when broadly stating that opportunity structure influences levels of empowerment. Especially without articulating what elements and processes of agency or structure one is referring to for specific contexts. It also can lead to the assumption that resources automatically translate into purposeful agency, which may not be the case (Sen, 1995). Thus there is an inherent risk that agency and empowerment could be defined as the socioeconomic characteristics of the agent - at both the conceptual level and in measurement.

Empowerment is also defined as choice and decision-making ability. As Kabeer (1999; 2003) argues, this definition of choice implies that there are other options that the agent can choose, which may or may not be the case, not to mention that agents may be unaware of the existence of other choices. Specifically, an illiterate person would have a very different realm of choices available than a literate person. In addition, choice removes the value component of the choice itself (Alkire and Deneulin, 2009). This nuance provides challenges to the measurement of choice which is generally reduced to the quantifiable decision-making ability. Decision-making ability can overlook the consideration of intrinsic value and how some choices align with one's deeper values and others do not.

Another set of authors - including those writing in the feminist literature - conceive of empowerment as the (re)distribution of power towards those who historically have had none (Wee et al. 2008; Batiwala, 2007). This opens up an array of issues relating to measurement such as how to define power, and how measurement itself is a form of power (Rose, 1999; Foucault, 2007).

Less discussed in development studies literature is the psychological domain of empowerment. The importance of the psychological domain of empowerment and agency has been outlined by the World Bank's Moving Out of Poverty Study (2009) and Rowlands' study on the "Power 
within” (1997). However these studies have conceptualised the psychological domain of agency as having only an instrumental value - supporting the move out of poverty or fighting against repressive power. Differently, Alkire (2005) has argued for the intrinsic importance of psychological capabilities, and proposed theoretical measures drawing from the social psychological literature (Ibrahim and Alkire 2007). Furthermore, using inductive research methods in a study of a neighbourhood on the urban fringe of Bamako, Klein (2014) found that the psychological domain of purposeful agency was central to initiatives people undertook to improve personal and community wellbeing. The psychological domain was both instrumental and intrinsically important to people in the study site (Klein, 2014; 2015) .

Specifically, through her inductive study, Klein (2014) found that two important concepts emerged as being central to intentional action: dusu (loosely translated as internal motivation ${ }^{1}$ ) and ka da I yèrè la (loosely translated as self-belief). Whilst seeming perhaps a little extraordinary at first, these concepts emerged time and time again when people were asked about what was necessary for them to overcome hardship in their lives.

This paper contributes towards a critical discussion of the measurement of agency; specifically the psychological domain of agency. Drawing on the empirical case study ${ }^{2}$ of a neighbourhood on the urban fringe of Bamako, Mali studied by Klein (2014), we examine the suitability of theoretical measures of the psychological domains of agency, against local psychological concepts of dusu and ka da I yèrè la. The paper is structured as follows: first we discuss some of the tensions around defining and measuring the psychological domains of agency and empowerment. Secondly, we describe the study site of the neighbourhood in Bamako, and explain the methods Klein (2014) used for gathering and analysing the data. Third we examine and compare the differences in results from the use of theoretical and local psychological measures (dusu and ka da I yèrè la). Building on these analyses, section four ends the paper with a discussion of the challenges in measuring the psychological domain of agency and empowerment. 


\section{Rethinking measures of psychological agency}

Measuring psychological agency and empowerment is inherently difficult. These difficulties arise from the way empowerment and purposeful agency are defined, along with the elusive and multidimensional nature of empowerment and agency themselves. Nonetheless, attempts to measure these concepts draw from the social psychology literature that has long shown the centrality of the psychological domain in agency: such as internal motivation (Ryan and Deci, 2000; 2006) and efficacy (Fernandez -Ballesteros et al, 2002; Bandura, 1997; 2006). Albert Bandura (1997) in his Self-Efficacy Theory, describes agency as "gained through development of personal efficacy that enables people to take advantage of opportunities and to remove environmental constraints guarded by those whose interests are served by them” (p. 477). Bandura (1997) argues that efficacy beliefs have an instrumental importance for the agent instrumental because self-efficacy leads to outcomes of human action. Efficacy can also relate to different levels of human action. For example, collective efficacy refers to the belief of a group in its ability (which is not necessarily the sum of individual members' efficacy as a group creates its own dynamic) and social efficacy refers to the individuals' belief that they can create change within their community or society (Fernandez-Ballesteros et al., 2002; Gecas, 1989).

Yet Bandura has been criticised for not distinguishing between actions that have value or do not have value to the agent, thus agents with efficacy alone may still be at risk of feeling coerced or compelled into undertaking actions that they do not value, even if they feel efficacious at it (Ryan and Deci, 2006; Alkire, 2005). The intrinsic element of psychological agency is articulated in social psychology, showing how acting according to the self's deeper values is essential to psychological well-being and human flourishing (Alkire 2005). Self-Determination Theory (SDT), championed by Ryan and Deci (2000), argues that all human beings are biologically wired towards growth "for their self-motivation and personality integration, as well as for the conditions that foster those positive processes" (p.68). Whilst this existence of a biological element towards the regulation of self-motivation is apparent, SDT argues that there is a need for agents to grow in a supportive environment in order for people to flourish - the requirements that SDT has articulated for such psychological well-being are relatedness, competence and autonomy. Autonomy is a major factor in internal motivation, yet Chirkov et al. 
(2003) argue that many have mistakenly defined autonomy as either independence or individualism relating to liberal political theory. In SDT, autonomy is true self-regulation, where the behaviour one exhibits is in accord with abiding to one's values and interests. Ryan and Deci (2000) describe autonomy on a scale where, at one end, is the autonomous intrinsically motivated self; and, at the other end, is a person who is extrinsically motivated. Specifically, Ryan and Deci (2000), describe the following levels of autonomy:

- External Regulation: Because of external pressure (to obtain rewards or avoid punishment).

- Introjected Regulation: Because doing so will gain approval by others or avoid guilt and shame.

- Integrated Regulation: Because activity is valuable and its pursuit is integrated with the person's other activities (Figure 1).

\section{Figure 1: SDT Motivation scale}

\section{Amotivation}

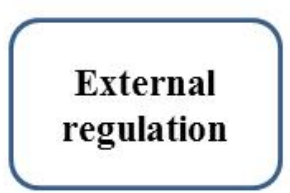

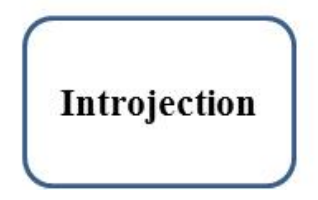

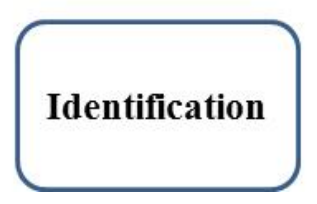

Intrinsic motivation

Source: Ryan (2012)

Development studies scholars have drawn on the concept of autonomy found in SelfDetermination Theory to develop measures of the intrinsic elements of agency, (Alkire et al. 2013, Ibrahim and Alkire 2007, Alkire 2007). Through the construction of the Relative Autonomy Index (RAI), Alkire et al (2013) have tried to find a suitable indicator for measuring autonomy. This measure initially was trialled on a sample of 220 people in Kerala, India, through adapting SDT measures of autonomy (Alkire, 2007). Alkire (2009) argues that the RAI is a reasonably robust measure for the concept of autonomy defined in SDT and the intrinsic elements of psychological agency (Alkire 2008, 2007, Alkire et al. 2013). 
The RAI is multi-dimensional in the sense that it examines the psychological domain of agency in different dimensions of agent's lives. For example, a woman may be empowered in her education, but go home to a husband who is controlling and abusive. This multi-dimensional aspect of the RAI is of particular significance: as Alkire (2007; 2008) argues, being empowered in one domain say, household decision making, may be different to how empowered a person is in the domain of making major decisions. Therefore it is important to think of agency and empowerment not as a universal phenomenon across all domains of people's lives, but instead as diverse, thus needing measures to examine the multi-faceted nature of agency and empowerment.

Nonetheless, it is well documented that the Euro/American psychology paradigm, on which theories such as Self-Efficacy theory and Self-Determination theory are based, is challenged by its tendency to universalise studies and concepts arising from liberal Western cultural contexts (Fernando 2014; Teo, 2015). Such research has a specific ontological and epistemological positioning with a presumption that there is a constant central processing mechanism that can be explained in its entirety (Mansfield, 2000). Regarding issues with measurement, Western psychological concepts can be tested outside the ontological and political environment they were intended (Igarashi, 2006; Gao, 2012); which is the large corpus of cross-cultural psychology (Stigler et al. 1990). Such critical scholarship raises a challenge for development scholars trying to measure the psychological domain; especially with regards to understanding what the psychological domain may mean to people apart from Western culture. This requires examining the psychological domain of agency through non-reductive frameworks that are located in the social, historical and cultural contexts of the self (Mkhize 2004, Hook, 2004).

Another issue arising from the literature effecting measurement is the orientation towards agency being located in the individual, overlooking agency as a collective practice. Collective agency stands apart from individual purposeful agency, identified as agents pursuing their notion of the good individually. In contrast, collective agency is where "the individual can pursue this perception of the good collectively by joining or participating in a group with similar goals” (Ibrahim 2006: 405). Consequently, collective agency is not just the sum of the agency of individual members in a group, but through the collaboration of individual agents, collective 
agency takes on a form of its own (Alkire and Deneulin, 2002); generally the collective capability of a group is more effective than any individual's capability alone (Ibrahim, 2006).

In this paper, we examine the use of the RAI theoretical measure against local concepts of $k a d a$ I yèrè la and dusu in order to examine closely the issues of measuring psychological dimensions of agency and empowerment with local and theoretical measures. Specifically, we will examine the difference between $k a$ da I yèrè la and dusu at both individual and collective levels. Furthermore we will examine the suitability of the RAI (theoretical measure) compared to ka $d a$ I yèrè la and dusu (local measure). We examine these measures in two domains important for respondents. First however, we will discuss the study site, and the methods used to collect the data used in this paper.

\section{Psychological agency on the urban fringe of Bamako: the data set}

We rely on the same data set used by Klein (2014), which documented the importance of ka da I yèrè la and dusu in undertaking initiatives to help personal and collective wellbeing, using inductive mixed methods.

\section{a) The Study Site}

The study site is a neighbourhood of 423 households on the urban fringe of Bamako, Mali's capital. The neighbourhood can be characterised as a site of major urbanization. Economic and social ties of the neighbourhood are very much mixed with those of the capital, which is only $15 \mathrm{~km}$ away; $70.9 \%$ of the people living in the neighbourhood were not born there, and had migrated from rural villages searching for work. The population has a myriad of social relations including relations of gender, where men and women have specific roles within the household and wider society. For example, the role of the man as the head of the family, where he is expected to financially provide for the family including food, clothes and shelter. The duty of women, specifically wives, is to care for the family, especially children, and to submit to their husbands. For instance, one woman that was interviewed from the neighbourhood middle class 
explains her conception of her role as a wife: "if your husband wants you to do this, then you must do this, you must not raise your voice beyond his voice ${ }^{3}$." The social roles of men and women can subsequently impact individual and collective deprivation and education levels, as well as decision-making abilities, across differing domains within the household and in the wider community (c.f. Klein, 2014).

Five domains emerged from the qualitative data as being important for women's and men's purposeful agency: minor household purchases, informants who had paid employment, informants who undertook unpaid household work, healthcare, and Islam. These domains were most significant to people’s purposeful agency for pursuing the aspiration of 'increasing personal and/or community hèrè (loosely translated as 'well-being' or the 'good life'). However how agency was expressed in these domains was not necessarily uniform due to the gendering of roles. For this reason, in this paper we focus on two of these domains: minor household purchases and treatment of serious health problems. The two domains are included because in the study site minor household decision-making was deemed a domain for women's agency, where minor household purchases generally fall under the responsibility of women. Differently, serious health problems of family members would be a domain for both men and women. As both domains have different social meanings, they were both important to include in the analysis.

\section{b) Methods}

The initial study by Klein (2014) used exploratory sequential mixed methods design which included, first, inductive qualitative methods, followed by quantitative methods to support qualitative findings.

Specifically, the initial research was conducted over a total of six and a half months, split among three trips. The first trip was a scoping and relationship-building mission for one month (December 2009), the second trip involved data collection for five months (November 2010 March 2011), and then the third trip reviewed initial results for one month (November 2011) as a 'double-checking exercise.' The qualitative methods used included, firstly, several months of observations while living in the neighbourhood, followed secondly by 26 life histories, then four 
focus groups (one each with men, women, male youth, and female youth) and another 25 key informant interviews. A household questionnaire was then employed to collect data from every household in the neighbourhood, in order to triangulate the qualitative findings about the psychological domain of agency and quantify levels of household deprivation and socioeconomic characteristics in the neighbourhood. There were 307 surveys completed out of a possible 423 households. A retest of the household questionnaire was then conducted with $12.2 \%$ of the population to test the stability of the questionnaire tool. Another 30 semi-structured interviews of the were conducted upon return where results were discussed and deliberated a year later.

What is interesting about this study is the inductive nature in which the psychological concepts of dusu and ka da I yèrè la emerged. The inductive nature of the research allowed Klein (2014) to understand the important elements of purposeful agency of those within the research. For example, the life histories Klein (2014) used were the primary aspect of the research in which the concepts of dusu and ka da I yèrè emerged. The semi-structured interview opened with participants describing daily activities, then key moments of their life from birth until the present that the informant thought were formative. If dusu and ka da I yèrè were expressed by the informant, their definition, meaning and beliefs about how one has dusu and ka da I yèrè were probed. This research methodology stands in contrast to many other psychological studies that either transpose concepts from studies carried out on Western subjects, or Western concepts used on subjects from other cultural settings under the banner of 'cross-cultural psychology'(Grabe, 2012). Yet transposing and extrapolating western concepts onto diverse cultural backgrounds is problematic (Asante, 1998). Anthropologists have long studied different cultures and societies showing how the 'self' was not a universal concept, but instead a concept varying across different cultural, temporal and spatial domains (Riesman 1990; 1998; Jackson 1990; Rose 1999).

The household survey was conducted, firstly, to record self-reported levels of dusu and ka da I yèrè, and then also to include theoretical measures of psychological agency such as the RAI. This provides an interesting set of variables to examine - self reported levels of dusu and $k a d a I$ yèrè with theoretical concepts which have been transposed from Western psychology. For the 
purpose of this paper, we are defining theoretical measures as those with Western epistemological positionings tested outside the ontological and political environment they were intended. We used the RAI measure which draws on Self-Determination theory as our theoretical measure. Differently, local measures are an examination of the psychological domain of agency through non-reductive frameworks that are located in the social, historical and cultural contexts of the self (dusu and ka da I yèrè). Whilst we have used the RAI as the theoretical measure in this study, for future research, it is possible that other Western psychological concepts may be of interest to test against local constructs (see measures used in Grabe 2012).

To quantify self-reported levels of dusu and ka da I yèrè la through the household questionnaire, respondents were asked to rate on a visual ladder of 10 rungs, firstly, how much dusu they felt they had to undertake initiatives in their family and secondly how much dusu they felt they had to undertake initiatives at a collective level. These two questions were then asked in regards to respondent's levels of ka da I yèrè la.

In the case of the RAI, which is an index for measuring autonomy based in Self Determination Theory (Ryan and Deci, 2000), the household questionnaire included a sequence of questions to reflect the levels of autonomy - external regulation, introjected regulation and integrated regulation- defining the index (as described in Figure 1). This sequence of questions (see below) were used in the household survey as theoretical measures of psychological agency.

For the domain of minor household purchases, informants were asked about how they made minor household purchases such as food or other daily items, providing feedback on the following statements:

a) I cannot make minor household purchases differently to how I do them.

b) I make minor household purchases because my spouse, another person, society, social organisations or my community insist that I make them.

c) I make minor household purchases according to what others expect of me or to obtain their approval. If I did not, they might blame me.

d) I make minor household purchases according to what I personally consider important. 
As for the healthcare dimension, informants were asked to answer the question "how would you solve a serious health problem?” choosing among;

a) I cannot face a serious health problem of my own differently from how I do.

b) If I have a serious health problem, I do what my spouse or some other person, society or social organisations insist that I do.

c) If I have a serious health problem, I act according to what other people expect of me or to get their approval. If I did not, they might blame me.

d) If I have a serious health problem, I do what I personally consider is important.

In all the question sequences above, a 'no control' option (option a.) was included. This question accounted for the possibility that the questions were 'not applicable' because it is the force of circumstances rather than any particular person's influence which drives the informant's behaviour (Chandler and Connell, 1987). The 'no control' was not included in the RAI because it had a number of meanings in different circumstances and does not necessarily indicate lack of autonomy (OPHI, 2013). For example, most people would say they had to work, because of force of circumstances as most people have not inherited wealth, which is not necessarily disempowering; because whilst it is a force of circumstance, people may also say they love what they do (OPHI, 2013).

Using these responses we computed a RAI score for each person using Ryan and Deci's autonomy scales. This was done by creating a weighted sum of the scores of each of the autonomy levels for each domain. So for each domain the formula was (-2) [external pressure response] + (-1) [introjected response] + (3) [integrated response] (OPHI, 2013).

The theoretical questions were translated from English to Bambara by a Bambara linguist. The questions were then tested with a group of ten households in the study site to pilot the household questionnaire tool. Minor adjustments were needed and subsequently included to ensure the concepts intended through the RAI were communicated as accurately as possible. 


\section{Patterns of agency: theoretical vis-a-vis local psychological measures in the urban fringe of Bamako}

In this section we present the results of the analysis by firstly examining the importance of ka da I yèrè la and dusu as enabling factors for people to undertake initiatives, and then we compare the patterns of responses at personal and community levels. Our aim with this latter analysis is to assess to what extent the level of analysis (personal, community) of ka da I yèrè la and dusu matters when conceptualising these concepts. Following these, our second group of analyses examines the relationship between 'local' measures of ka da I yèrè la and dusu and RAI measures.

a) Ka da I yèrè la and dusu

\section{i. Purposeful Agency}

From interviews, focus groups and observations, people described important activities to support the community, as well as activities for the personal and intermediate domain. Initiatives in the personal/immediate domain included activities such as farming, running a small business, working in the nearest town, household chores, market gardening (Figure 2); whereas initiatives people undertook at the community level included being part of a community association, having a leadership role in the community, helping disadvantaged people, impliemented their own community development projects (Figure 3).

Figure 2: Types of initiatives people undertake to improve personal wellbeing 


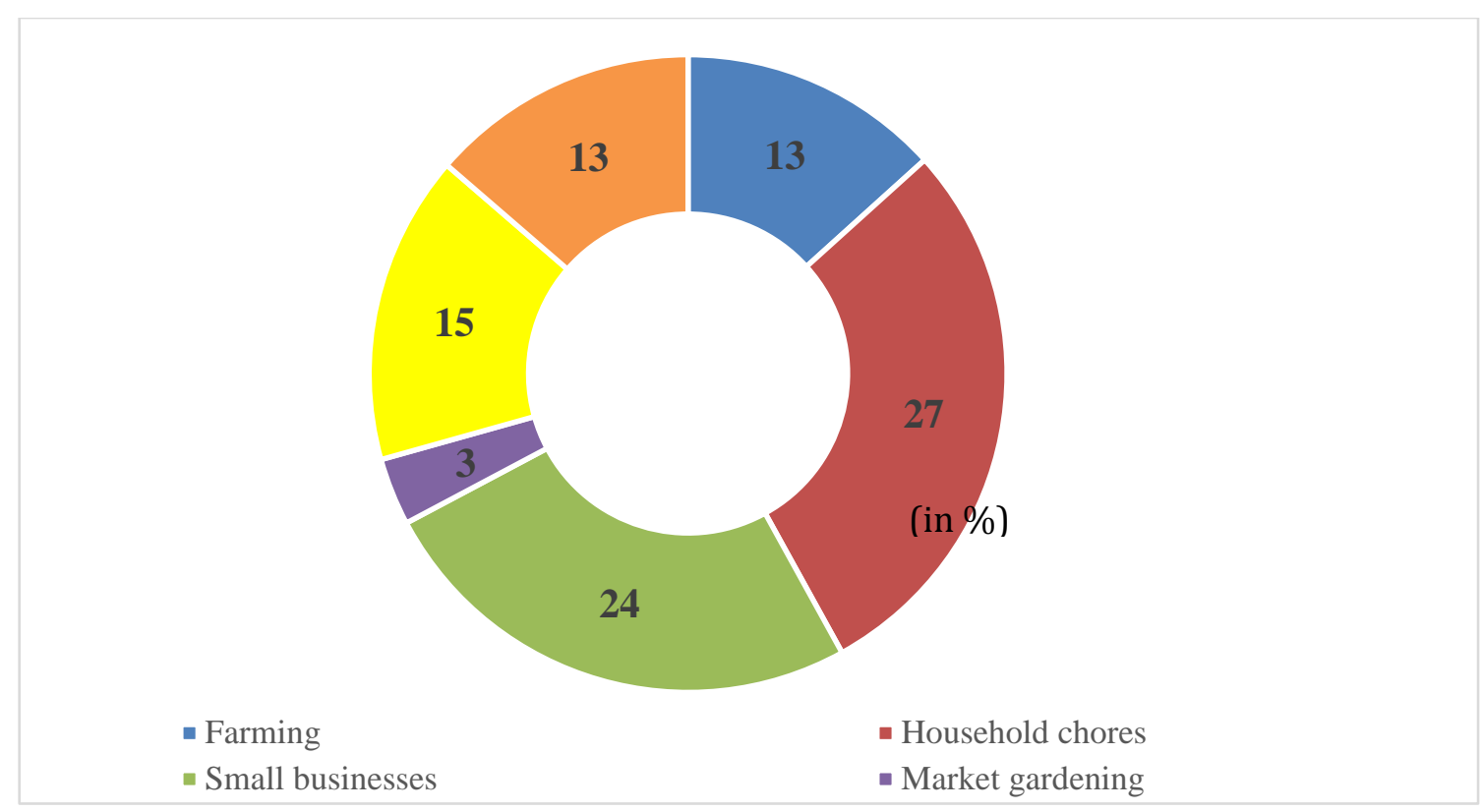

Figure 3: Types of initiatives people undertake to improve community wellbeing

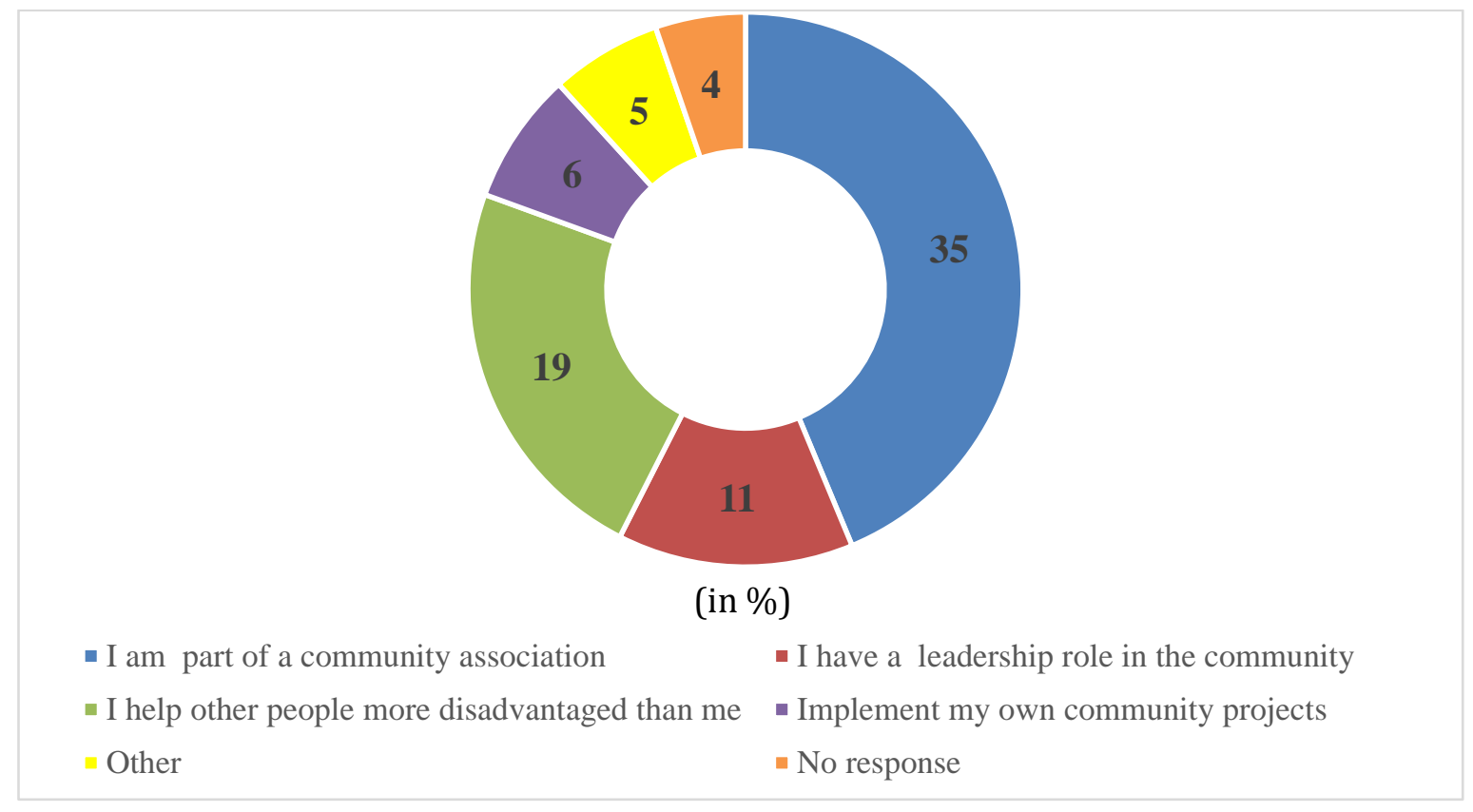

A comparison of these two types of initiatives shows that in the personal domain household chores and running small businesses are the two types of initiatives that people undertake the most to improve their personal wellbeing ( $27 \%$ and $24 \%$ of respondents, respectively), whereas 
at the community level, being part of a community association is the predominant initiative that people undertake to improve their community wellbeing (35\% of respondents); this if followed by helping disadvantaged people (19\% of respondents). It is interesting to note that market gardening and implementing one's own community development project are the personal and community initiatives, respectively, that people undertake the least as a means to improve their personal and community wellbeing, respectively.

\section{ii) Psychological domain of purposeful agency - Ka da I yèrè la and dusu}

Respondents articulated that ka da I yèrè la and dusu underpinned this purposeful agency. Klein (2014) found that ka da I yèrè la and dusu fortified informants' conceptions of purposeful agency and were not only intrinsically valuable but also instrumental for people to improve their personal and collective well-being. The psychological domain is relational, meaning that social

processes are involved in the production of ka da I yèrè la and dusu. For example, dusu came from watching others succeed, which generated positive envy to help pursue initiatives that people valued. Ka da I yèrè la came from encouragement and watching other people succeed, which instilled a self-belief. Gender, age, formal education level and deprivation were cited much less by informants as being conditions of dusu and ka da I yèrè la, suggesting these concepts cannot be reduced to agents’ socio-economic characteristics. Finally, Klein (2014) found that dusu and ka da I yèrè la through underpinning purposeful agency, play a role in processes of change and social development in the neighbourhood.

Table 1 illustrates the importance that dusu and ka da I yèrè la have to respondents when they were asked to identify the three most important factors enabling them to undertake either initiatives to improve family wellbeing or community wellbeing. Although having enough financial means was identified as the most important factor that enable people to undertake initiatives for their family’s wellbeing (32\% of respondents) or their community's wellbeing (29\%) having either dusu or ka da I yèrè la were identified as the second and third most important factors that people consider important to have in order to undertake initiatives to improve family and community wellbeing. Relationships were also important in the case of initiatives to improve community wellbeing. 
In order to assess the level of ka da I yèrè la and dusu that people felt to undertake initiatives in the household survey, people were asked to self-rate the levels of each of these two concepts at individual and community levels. Specifically, people were asked to rate their ka da I yèrè la/ dusu on a cardinal scale from 1-10 for both personal and community initiatives.

Table 1: Most important factors that able people to undertake initiatives

\begin{tabular}{|c|c|c|c|c|c|c|}
\hline \multirow[b]{2}{*}{ Factors } & \multicolumn{3}{|c|}{$\begin{array}{c}\text { For your family's } \\
\text { wellbeing }\end{array}$} & \multicolumn{3}{|c|}{$\begin{array}{c}\text { For your community's } \\
\text { wellbeing }\end{array}$} \\
\hline & $\begin{array}{l}\text { Top } 1 \\
\text { (\%) } \\
\end{array}$ & $\begin{array}{l}\text { Top } 2 \\
\text { (\%) } \\
\end{array}$ & $\begin{array}{l}\text { Top } 3 \\
\text { (\%) }\end{array}$ & $\begin{array}{l}\text { Top } 1 \\
\text { (\%) } \\
\end{array}$ & $\begin{array}{l}\text { Top } 2 \\
(\%)\end{array}$ & $\begin{array}{l}\text { Top } 3 \\
(\%) \\
\end{array}$ \\
\hline To have enough financial means & 32 & 15 & 14 & 29 & 10 & 9 \\
\hline Being educated & 22 & 16 & 9 & 20 & 14 & 6 \\
\hline $\begin{array}{l}\text { Relationships (family, friends, } \\
\text { peers) }\end{array}$ & 7 & 14 & 4 & 7 & 15 & 8 \\
\hline To have Hami (Aspirations) & 9 & 18 & 11 & 7 & 13 & 10 \\
\hline To have Dusu & 19 & 20 & 19 & 12 & 15 & 13 \\
\hline To have Ka I yèrè la & 6 & 8 & 28 & 4 & 9 & 21 \\
\hline To have choice in what I do & 2 & 7 & 7 & 1 & 4 & 8 \\
\hline I don’t know / No answer & 3 & 3 & 8 & 21 & 21 & 24 \\
\hline
\end{tabular}

\section{iii)Personal vis a vis community ka da I yèrè la and dusu}

Figure 4 plots the distribution of self-ratings people gave for both $d u s u$ at the family level (mean 8.74, variance 1.62) and dusu at the community level (mean 8.48, variance 2.84). It is interesting to observe from these histograms that the self-ratings across personal and community levels are not homogenous. While in the case of dusu for family initiatives ("Dusuf”) the smallest self rating value was 5 , in the case of community initiatives ("Dusuc"), people self-reported 1 as the 
minimum, showing a larger range of variation in self-reported levels of dusu for community initiatives. However, in both self-rated levels the highest concentration of responses was placed at ladder values of 8 and 10.

Figure 4: Dusu histograms of self-ratings: personal vis a vis community

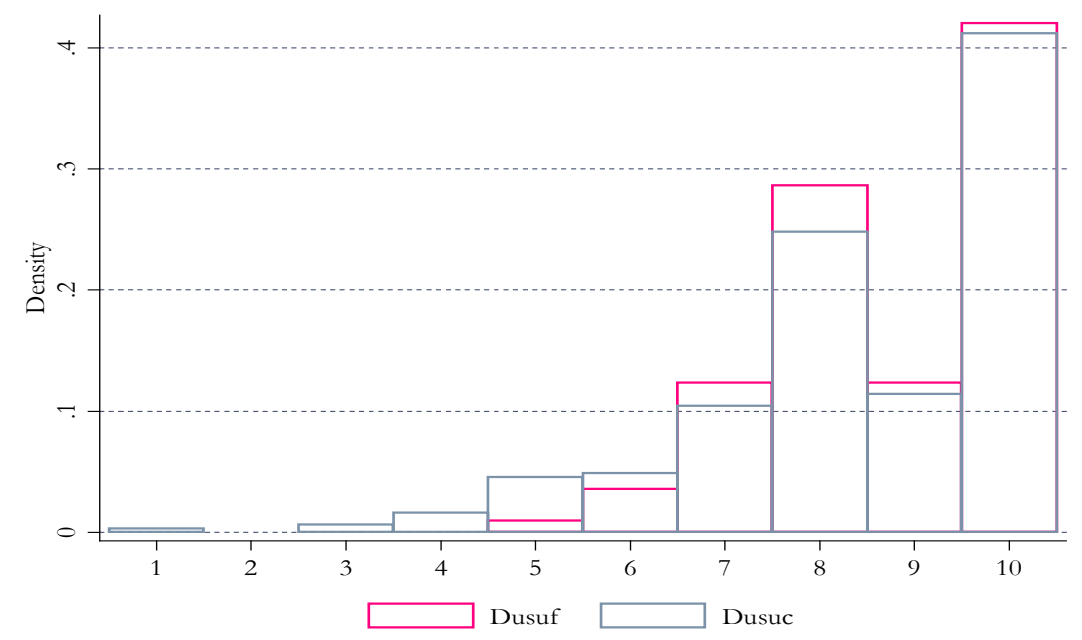

Furthermore, a similar distribution emerges in the case of self-ratings people gave for both $k a d a$ I yèrè la at the family level (mean 8.47, variance 3.10) and ka da I yèrè la at the community level (mean 8.88, variance 2.40). As shown in Figure 5 again, we find a difference in the range of selfratings for the family and community level. Specifically, the self-rating for family initiatives starts at 3 , yet community initiatives starts at 1 . Nonetheless, both self-rated levels of 8 and 10 had the highest concentration of responses. 
Figure 5: Ka da I yèrè la histogrammes of self-ratings: personal vis a vis community

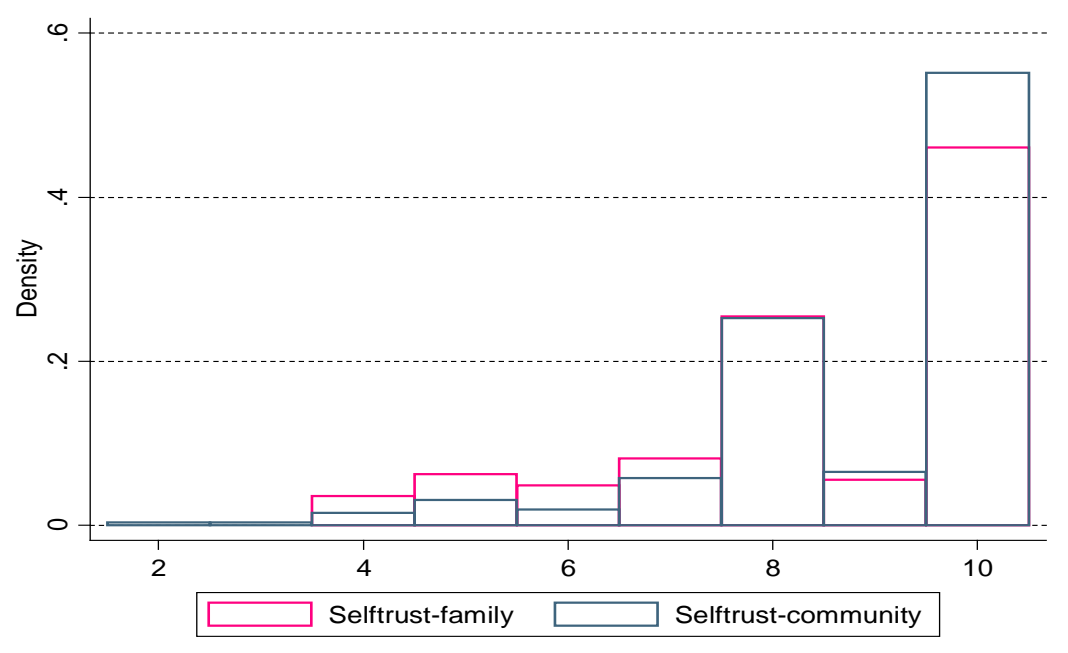

The difference between the personal and community histograms provides a hint of the need to measuring personal and community ka da I yèrè la and dusu separately. To explore this further we look at the concordance of the self-reporting scores on each of the two ladder scales: family and community initiatives for both ka da I yèrè la and dusu. This will enable us assessing to what extent people had the same score in family and community initiatives either for ka da I yèrè la or dusu. Table 2 reports the concordance correlation coefficient (Lin, 1989, 2000) ${ }^{4}$ between personal and community ladder scores for each of the concepts of ka da I yèrè la and dusu. From this table we see that there is a low concordance of 0.369 between the two levels of family/personal dusu and community dusu, and moderate concordance in the case of $k a d a I$ yèrè la with a value of 0.583 .

This concordance correlation coefficient suggests that dusu at the two different levels cannot be collapsed under one measure. A similar conclusion also emerges when thinking about the concordance of ka da I yèrè la underpinning initiatives needed at the individual level compared to those at community level. 
Table 2: Concordance of family and community dusu and ka da I yèrè la

\begin{tabular}{|c|c|c|}
\hline \multicolumn{2}{|c|}{ Concordance correlation coefficient (Lin, 1989, 2000) } & \multirow{3}{*}{$\begin{array}{l}\text { Statistical } \\
\text { significance } \\
* * * \\
\end{array}$} \\
\hline \multirow{3}{*}{ Dusu -family-wellbeing } & Dusu -community-wellbeing & \\
\hline & 0.369 & \\
\hline & $\begin{array}{l}\text { Ka I yèrè la-community- } \\
\text { wellbeing }\end{array}$ & \\
\hline \multirow[t]{2}{*}{ Ka I yèrè la-family-wellbeing } & 0.583 & $* * *$ \\
\hline & Ka I yèrè la-family-wellbeing & \\
\hline \multirow[t]{2}{*}{ Dusu -family-wellbeing } & 0.531 & $* * *$ \\
\hline & $\begin{array}{l}\text { Ka I yèrè la-community- } \\
\text { wellbeing }\end{array}$ & \\
\hline Dusu -community-wellbeing & 0.520 & $* * *$ \\
\hline
\end{tabular}

\section{b) The Relative Autonomy Index vis a vis ka da I yèrè la and dusu}

In order to analyse the possible association between theoretical and local psychological measures of agency we compare the patterns of responses arising from the Relative Autonomy Index (RAI) with those resulting from self-ratings of ka da I yèrè la and dusu. As introduced before, questions regarding the RAI were included in the household questionnaire as a way of examining the usefulness and accuracy of theoretical measures against self -reported levels of dusu and $k a$ da I yèrè la. To perform these comparisons we examine the patterns of responses of the RAI and of each of its components with the self-reported measures of dusu and ka da I yèrè la.

We shall recall that the RAI considers three levels of autonomy (three components): external regulation (ER), introjected regulation (IR) and integrated regulation (ITR). ER and ITR are placed at the extremes of the behaviour scale. While ER refers to a behaviour that one exhibits because of external pressure - this is to obtain rewards or avoid punishment, ITR refers to behaviours where the activity undertaken is valuable and its pursuit is integrated with the person's other activities. In between of these two components, we find IR that concerns those behaviours exhibited to gain the approval by others or avoid guilt and shame. Each respondent was required to agree or disagree in each of these three components for a given statement. 
In order to view the responses to RAI questions against self-ratings of ka da I yèrè la and dusu, these three components of the RAI (by domain) were re-coded into cardinal variables as shown in Table 3. This recoding assigns a negative score to responses that agree with ER and IR, and to responses that disagree with ITR. Similarly, we code positively all responses that disagree with ER and IR, and agree with ITR. Note that this coding is neutral or symmetric. This means it assigns equal weight to either agreements or disagreements with the difference resting upon the sign.

Table 3: Recoding of the components of the RAI

\begin{tabular}{|c|c|c|}
\hline \multirow{2}{*}{$\begin{array}{l}\text { Self- determination } \\
\text { scale of autonomy }\end{array}$} & \multicolumn{2}{|c|}{ Score } \\
\hline & Agree & Disagree \\
\hline External regulation & -1 & 1 \\
\hline Introjected regulation & -1 & 1 \\
\hline Integrated regulation & 1 & -1 \\
\hline
\end{tabular}

In Table 4 we report the frequency of responses to each of these three components. It is interesting to see that in the domain of household decision-making most people (80\% or more) tend to agree with any of the three possible types of regulation. Thus, in this domain there does not seem to emerge any specific behaviour. However, in the case of health we do observe a predominant agreement rate in ITR (96\%) compared to ER (50\%). These frequencies seem to suggest that people agree that the initiatives they undertake to improve their wellbeing in the health domain are valuable in themselves and not so much due to external pressure (50\%). 


\section{Table 4: Frequency of responses by RAI component}

\begin{tabular}{|c|c|c|c|}
\hline Domain & & Regulation & \\
\hline \multirow{3}{*}{$\begin{array}{l}\text { Hous ehold } \\
\text { decision- } \\
\text { making }\end{array}$} & External & $\begin{array}{l}\text { Agree } \\
\text { Disagree }\end{array}$ & $\begin{array}{l}81 \\
19\end{array}$ *** \\
\hline & Introjected & $\begin{array}{l}\text { Agree } \\
\text { Disagree }\end{array}$ & $\begin{array}{l}85 \\
15\end{array}$ \\
\hline & Integrated & $\begin{array}{l}\text { Agree } \\
\text { Disagree }\end{array}$ & $\begin{array}{c}97 \\
3\end{array} * * *$ \\
\hline \multirow{3}{*}{ Health } & External & $\begin{array}{l}\text { Agree } \\
\text { Disagree }\end{array}$ & $\begin{array}{l}50 \\
50\end{array}-$ \\
\hline & Introjected & $\begin{array}{l}\text { Agree } \\
\text { Disagree }\end{array}$ & $\begin{array}{l}66 \\
34\end{array}$ *** \\
\hline & Integrated & $\begin{array}{l}\text { Agree } \\
\text { Disagree }\end{array}$ & $\begin{array}{r}96 \\
4\end{array}$ *** \\
\hline
\end{tabular}

A cross-analysis of the RAI responses with levels of dusu and ka da I yèrè la will help us elucidate much better the behaviours behind the RAI responses. Specifically we are interested in finding out the possible direction (sign) of the association between levels of local measures and levels of autonomy, in other words if people with high(low) dusu and ka da I yèrè la also had high(low) levels of autonomy.

The cross-tabulation between dusu and ka da I yèrè la with the different types of regulation composing the RAI measure shows a consistent finding in the case of ER. Examining both domains, household-decision making and severe health issues, we observe that people who exhibit a high score (category: 8-10) on local measures of dusu and ka da I yèrè la, either at the family or community levels, tend to disagree more frequently with ER, i.e. with a motivation led by fear or punishment. This is seen through the greater response frequencies of $87 \%$ or more across domains and levels (Table 5, panels A and B). Despite the similar pattern across domains and levels it is worth noting that the gap between agreement and disagreement at the very top of the distribution of self-rated scores is greater in the severe health domain, compared to the household decision-making one, for dusu community initiatives (-17) and for both levels of $k a$ da I yèrè la (-22 for the personal level and -11 for the community level) (Table 6, panels $A$ and 
B). In contrast, we also observe that when people self-place themselves with a moderate score of dusu or ka da I yèrè la (category: 5-7) they tend to agree more with ER in both domains. This pattern seems to point towards a negative association between ER and local measures of autonomy.

Table 5: Dusu and Ka da I yèrè la vs autonomy components (\%)

\section{Panel A}

\begin{tabular}{|c|c|c|c|c|c|c|c|c|}
\hline \multirow[t]{2}{*}{ Domain } & \multirow[t]{2}{*}{$\begin{array}{c}\text { RAI } \\
\text { Regulation }\end{array}$} & & \multicolumn{3}{|c|}{$\begin{array}{c}\text { Doosu } \\
\text { family initiatives } \\
\text { ladder scale categories } \\
\text { (row \% add up to 100) }\end{array}$} & \multicolumn{3}{|c|}{$\begin{array}{c}\text { Doosu } \\
\text { community initiatives } \\
\text { ladder scale categories } \\
\text { (row \% add up to 100) }\end{array}$} \\
\hline & & & 1-4 & $5-7$ & 8-10 & $1-4$ & $5-7$ & 8-10 \\
\hline \multirow{6}{*}{$\begin{array}{l}\text { Household } \\
\text { decision- } \\
\text { making }\end{array}$} & \multirow[t]{2}{*}{ External } & Agree & \multirow{6}{*}{ n.a } & 19 & $\overline{81}$ & 3 & 22 & 75 \\
\hline & & Disagree & & 11 & 89 & 0 & 13 & 87 \\
\hline & \multirow[t]{2}{*}{ Introjected } & Agree & & 17 & 83 & 2 & 23 & 75 \\
\hline & & Disagree & & 21 & 79 & 0 & 7 & 93 \\
\hline & \multirow[t]{2}{*}{ Integrated } & Agree & & 18 & 82 & 2 & 20 & 78 \\
\hline & & Disagree & & 10 & 90 & 0 & 20 & 80 \\
\hline \multirow{6}{*}{ Health } & \multirow[t]{2}{*}{ External } & Agree & \multirow{4}{*}{ n.a } & 21 & 79 & 1 & 29 & 70 \\
\hline & & Disagree & & 13 & 87 & 3 & 10 & 87 \\
\hline & \multirow{2}{*}{ Introjected } & Agree & & 12 & 88 & 3 & 18 & 80 \\
\hline & & Disagree & & 27 & 73 & 1 & 25 & 75 \\
\hline & \multirow[t]{2}{*}{ Integrated } & Agree & & 0 & 100 & 2 & 20 & 78 \\
\hline & & Disagree & & 18 & 82 & 0 & 18 & 82 \\
\hline
\end{tabular}

\section{Panel B}

\begin{tabular}{|c|c|c|c|c|c|c|c|c|}
\hline \multirow[t]{2}{*}{ Domain } & \multirow[t]{2}{*}{$\begin{array}{c}\text { RAI } \\
\text { Regulation }\end{array}$} & & \multicolumn{3}{|c|}{$\begin{array}{c}\text { Ka da yere la } \\
\text { family initiatives } \\
\text { ladder scale categories } \\
\text { (row \% add up to } 100 \text { ) }\end{array}$} & \multicolumn{3}{|c|}{$\begin{array}{c}\text { Ka da yere la } \\
\text { community initiatives } \\
\text { ladder scale categories } \\
\text { (row \% add up to 100) }\end{array}$} \\
\hline & & & $1-4$ & $5-7$ & 8-10 & $1-4$ & $5-7$ & 8-10 \\
\hline \multirow{6}{*}{$\begin{array}{l}\text { Household } \\
\text { decision- } \\
\text { making }\end{array}$} & External & Agree & 5 & 21 & 74 & 3 & 11 & 86 \\
\hline & & Disagree & 0 & 11 & 89 & 0 & 10 & 90 \\
\hline & Introjected & Agree & 4 & 21 & 75 & 3 & 11 & 86 \\
\hline & & Disagree & 0 & 14 & 86 & 0 & 10 & 90 \\
\hline & Integrated & Agree & 4 & 20 & 76 & 2 & 10 & 87 \\
\hline & & Disagree & 0 & 10 & 90 & 0 & 20 & 80 \\
\hline \multirow{6}{*}{ Health } & Extemal & Agree & 7 & 26 & 67 & 3 & 17 & 81 \\
\hline & & Disagree & 0 & 11 & 89 & 2 & 6 & 92 \\
\hline & Introjected & Agree & 1 & 18 & 81 & 3 & 10 & 87 \\
\hline & & Disagree & 10 & 21 & 69 & 1 & 12 & 87 \\
\hline & Integrated & Agree & 4 & 19 & 77 & 2 & 11 & 86 \\
\hline & & Disagree & 0 & 9 & 91 & 0 & 0 & 100 \\
\hline
\end{tabular}


In the case of IR, we observe a similar pattern in the household-decision making domain, but a reverse one in the health one. In the former, people exhibiting high autonomy through local measures of dusu or ka da I yèrè la tend to disagree more with a behaviour led by guilt avoidance and shame, or need to gain approval by others, while in the latter, the opposite seems to be the case. This is reflected in the negative gaps between agreement and disagreement with IR in the household decision-making domain, when crossed with high levels of dusu or ka da I yèrè la and through the positive gaps in the case of health issues (Table 6, panels A and B).

In the health domain, people who self-rate as having high dusu or ka da I yèrè la do tend to agree more frequently with IR as the reason for undertaking initiatives towards improving the wellbeing of their families or communities in health issues. It may be expected that, when facing major health care issues for their families or communities, people will feel committed to undertake initiatives seeking to help them thus avoiding to feel any guilt or shame for not doing so.

Lastly, in the case of ITR we find a contrasting pattern across domains and levels. We observe high agreement rates with ITR at the very top of the distribution of local autonomy measures of dusu family/personal in the health domain (Table 5, panel A) and ka da I yèrè la community in the household-decision making domain, (Table 5, panel B) which are corroborated by the positive agreement-disagreement gaps of 18 and 7 percentage points respectively (Table 6, panels A and B). An opposite conclusion emerges in the other cases. This indicates that initiatives that are seen valuable and their pursuit is integrated with the person's other activities happen in two different instances: a) in the health area for people who exhibit high local autonomy in terms of dusu and undertake initiatives towards improving the wellbeing of their families or theirs; and b) in the household decision-making domain for people who exhibit high ka da I yèrè la and who undertake initiatives for the wellbeing of their communities. 
Table 6: Dusu and Ka da I yèrè la vs autonomy components

Agreement - Disagreement Gaps (\%)

Panel A

\begin{tabular}{|c|c|c|c|c|c|c|c|c|}
\hline \multirow[t]{2}{*}{ Domain } & \multirow[t]{2}{*}{ Regulation } & \multirow[t]{2}{*}{$\begin{array}{l}\text { Gap } \\
\text { (\%) }\end{array}$} & \multicolumn{3}{|c|}{$\begin{array}{c}\text { Doosu } \\
\text { family initiatives } \\
\text { ladder s cale categories }\end{array}$} & \multicolumn{3}{|c|}{$\begin{array}{c}\text { Doosu } \\
\text { community initiatives } \\
\text { ladder scale categories }\end{array}$} \\
\hline & & & 1-4 & $5-7$ & 8-10 & $1-4$ & $5-7$ & 8-10 \\
\hline \multirow{3}{*}{$\begin{array}{l}\text { Household } \\
\text { decision- } \\
\text { making }\end{array}$} & \multirow{3}{*}{$\begin{array}{l}\text { External } \\
\text { Introjected } \\
\text { Integrated }\end{array}$} & \multirow{3}{*}{$\begin{array}{c}\text { Agree- } \\
\text { Disagree }\end{array}$} & \multirow{3}{*}{ n.a } & 8 & -8 & 3 & 9 & -12 \\
\hline & & & & -4 & 4 & 2 & 16 & -18 \\
\hline & & & & 8 & -8 & 2 & 0 & -2 \\
\hline \multirow{3}{*}{ Health } & \multirow{3}{*}{$\begin{array}{l}\text { External } \\
\text { Introjected } \\
\text { Integrated }\end{array}$} & \multirow{3}{*}{$\begin{array}{c}\text { Agree- } \\
\text { Disagree }\end{array}$} & \multirow{3}{*}{ n.a } & 8 & -8 & -1 & 19 & -17 \\
\hline & & & & -16 & 16 & 2 & -7 & 5 \\
\hline & & & & -18 & 18 & 2 & 2 & -4 \\
\hline
\end{tabular}

\section{Panel B}

\begin{tabular}{|c|c|c|c|c|c|c|c|c|}
\hline \multirow[t]{2}{*}{ Domain } & \multirow[t]{2}{*}{ Regulation } & \multirow[t]{2}{*}{$\begin{array}{l}\text { Gap } \\
\text { (\%) }\end{array}$} & \multicolumn{3}{|c|}{$\begin{array}{c}\text { Ka da ye re la } \\
\text { family initiatives } \\
\text { ladder scale categories }\end{array}$} & \multicolumn{3}{|c|}{$\begin{array}{c}\text { Ka da yere la } \\
\text { community initiatives } \\
\text { ladder scale categories }\end{array}$} \\
\hline & & & $1-4$ & $5-7$ & 8-10 & $1-4$ & $5-7$ & 8-10 \\
\hline \multirow{3}{*}{$\begin{array}{l}\text { Household } \\
\text { decision- } \\
\text { making }\end{array}$} & \multirow{3}{*}{$\begin{array}{l}\text { External } \\
\text { Introjected } \\
\text { Integrated }\end{array}$} & \multirow{3}{*}{$\begin{array}{c}\text { Agree- } \\
\text { Disagree }\end{array}$} & 5 & 10 & -15 & 3 & 1 & -4 \\
\hline & & & 4 & 7 & -11 & 3 & 1 & -4 \\
\hline & & & 4 & 10 & -14 & 2 & -10 & 7 \\
\hline \multirow{3}{*}{ Health } & \multirow{3}{*}{$\begin{array}{l}\text { External } \\
\text { Introjected } \\
\text { Integrated }\end{array}$} & \multirow{3}{*}{$\begin{array}{c}\text { Agree- } \\
\text { Disagree }\end{array}$} & 7 & 15 & -22 & 1 & 10 & -11 \\
\hline & & & -9 & -3 & 12 & 2 & -1 & 0 \\
\hline & & & 4 & 10 & -14 & 2 & 11 & -14 \\
\hline
\end{tabular}

To complement these cross-tabulations, we computed the Pearson bivariate correlations between the three components of the RAI and self-ratings of dusu and ka da I yèrè la. These correlations corroborate our preceding findings as they show lack of association between local and theoretical measures in both the household decision making domain and major health care decisions domain (Table 7).

These cross-analyses and correlations indicate that there is no overall and consistent pattern suggesting that high levels of autonomy correspond with high levels of dusu and ka da I yèrè la. Nor do we see that low levels of autonomy correspond with low levels of dusu and ka da I yèrè la. This suggests that theoretical and local measures of autonomy are different concepts and thus measure different aspects of psychological agency. Therefore any measurement exercise of psychological agency requires a comprehensive approach that includes local measures of autonomy together with theoretical ones. 
Table 7: Correlations between Dusu and Ka da I yèrè la and autonomy components

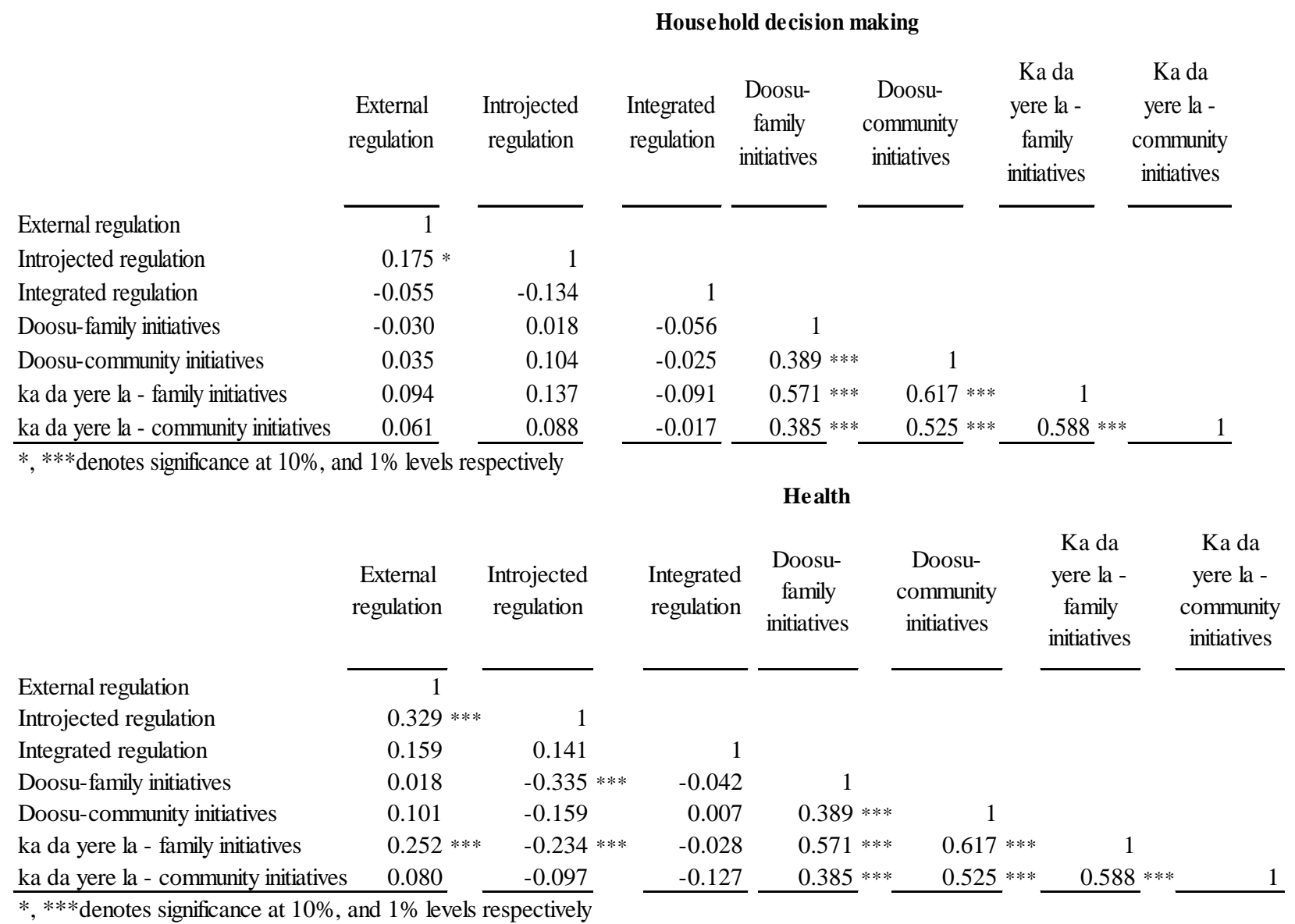

Lastly, we also examined possible different weightings of the RAI, to see if this improved the relationship between $k a$ da yèrè la and dusu and theoretical measures. Specifically, we tested four possible variations of the RAI - each featuring different weightings for the three components; external regulation, introjected regulation and internal regulation. Firstly, we tested the original formula with the extreme in the weightings, this is assigning the highest values to either external regulation or integrated regulation Secondly, we tested the reverse of the weightings to the original formula. Thirdly, we gave each component the same weighting. Fourthly, we gave equal weightings to the positive and negative values of the components (Table 8). Our conclusions on the absence of a clear association between local and theoretical measures remain with these alternative weighting schemes. 


\section{Table 8: Formula variations of RAI weightings}

\begin{tabular}{|l|c|c|c|}
\hline & $\begin{array}{c}\text { External } \\
\text { Regulation }\end{array}$ & Introjected Regulation & Integrated Regulation \\
\hline Original Formula & -2 & -1 & 3 \\
\hline $\begin{array}{l}\text { Extreme weighting } \\
\text { (EX) }\end{array}$ & -3 & -2 & 3 \\
\hline $\begin{array}{l}\text { Reverse of the original } \\
\text { formula } \\
\text { (Reverse) }\end{array}$ & -3 & -1 & 2 \\
\hline $\begin{array}{l}\text { Same values } \\
\text { (Same) }\end{array}$ & -1 & -1 & 1 \\
\hline $\begin{array}{l}\text { Equal Weighting } \\
\text { (Equal) }\end{array}$ & -1 & -1 & 2 \\
\hline
\end{tabular}

\section{Discussion}

In this paper, we have firstly shown how the level of agency (individual or collective) matters to the people in the study site and why psychological measures should not collapse such levels under one measure. We have also explored the relationship between self-reported levels of dusu and ka da yèrè la with the RAI. Firstly we looked at the relationship between the components of the RAI and dusu and $k a$ da yèrè la at both the level of family initiatives and community initiatives. We found that, when examining the distribution of RAI components against dusu and ka da yèrè la levels, there is no pattern of association. This was true for the two domains of household decision making and major health care decisions. These findings suggest that high levels of autonomy do not correspond with high levels of dusu and ka da I yèrè la. Also, low levels of autonomy do not correspond with low levels of dusu and ka da I yèrè la. Finally, we tried different variations of the weightings of the RAI formula to see if this made a difference to the relationship with dusu and ka da yèrè la. Again, such analysis showed a null or a weak relationship with self-reported levels of dusu and ka da yèrè la. Such results indicate that both the phenomena of RAI and dusu and ka da yèrè la capture different aspects of psychological wellbeing. These findings are largely supported by bivariate correlations between self-reported dusu and ka da yèrè la and the components of the RAI and with the RAI itself. 
Whilst this study is limited in that the results have come from an examination of one neighbourhood on the urban fringe of Bamako, and we have only tested one iteration of a theoretical measure, it does have implications for further studies of measures of the psychological dimension of agency and empowerment. These studies may benefit from the approach followed in this paper, and could possibly replicate the analysis by applying an inductive method (c.f. Klein, 2014) and comparing local vis-vis the RAI or any other theoretical measure (c.f Grabe, 2012).

In the introduction, we outlined some of the debates regarding different ontological and epistemological approaches to the psychological dimension of agency. Much of the research coming from psychology views the psyche as a phenomenon that can be understood in its entirety. This has led to specific epistemological approaches to studying the psychological domain, specifically through concepts identified in Western subjects, which have then been relocated to people living in different cultural contexts. Critical psychology scholars have contested this approach, arguing that the psyche is much more discursive, underpinned by relations of power (Mkhize, 2004: Hook, 2004). If power shapes the psyche, then cultural, political, social, spatial and temporal elements challenge the positivist approach to understanding the psyche. This, in turn, challenges the assumption of universal applicability of theoretical concepts developed in the West, and encourages researchers to use inductive methods to understand other psychological constructs. This current study follows this logic, using inductive mixed methods to locate locally identified psychological concepts. We have then examined dusu and $k a$ da yèrè la in relation to the theoretical measure of RAI stemming from SelfDetermination Theory, finding that these measures were measuring something different to local psychological constructs. These results, whilst modest, suggest that further empirical work examining both theoretical and local measures is important. Understanding the difference between local and theoretical measures can shed more light on the effects of using measures stemming from Western psychological measures as theoretical measures of psychological agency based on the Western psyche may silence local understandings of agency. 


\section{References}

Alkire, S. 2005. "Subjective Quantitative Studies of Human Agency." Social Indicators Research no. 74:43.

Alkire, S. 2007. "Measuring Agency: Issues and Possibilities." Indian Journal of Human Development no. 1 (1):169-178.

Alkire, S. 2008. "Concepts and Measures of Agency." In Arguments for a Better World: Essays in Honour of Amartya Sen; Volume 1: Ethics, Welfare and Measurement, edited by K Basu and R Kanbur. Oxford: Oxford University Press.

Alkire, S, and S. Deneulin. 2002. "Individual Motivation, its Nature, Determinants, and Consequences for Within-Group Behaviour." In Group Behaviour and Development: Is the Market Destroying Cooperation?, edited by Judith Heyer, Frances Stewart and Rosemary Thorp. Oxford University Press.

Alkire, S, and S. Deneulin. 2009. "The Human Development and Capability Approach." In An Introduction to the Human Development and Capability Approach: Freedom and Agency. EarthScan.

Alkire, S, R. Meinzen-Dick, A. Peterman, A. Quisumbing, G. Seymour, and A. Vaz. 2013. "The Women's Empowerment in Agriculture Index." Oxford Poverty and Human Development Initiative no. Working Paper 58.

Alsop, R, M. Frost Bertelsen, and J. Holland. 2006. Empowerment in Practise: From Analysis to Implementation. World Bank.

Asante, Molefi K. 1998. Afocentricity: A theory of social change. Tranton, NJ: Africa World Press.

Bandura, A. Self - efficacy: the exercise of control. Worth Publishers 1997.

Bandura, A 2006. "Guide For Constructing Self-Efficacy Scales." In Self Efficacy Beliefs of Adolescents, edited by Frank Pajares and Tim Urdan, 307-337. Information Age Publishing.

Batiwala, S 2007. "Taking the power out of empowerment - experiential account." Development in Practice no. 17 (4):557-565.

Bourdieu, P. 1977. Outline of a Theory of Practice: Cambridge University Press.

Chambers, R. 1997. Whose reality counts? Putting the first last: ITDG Publishing. 
Chandler, C, and J. Connell. 1987. "Children's intrinsic, extrinsic and internalized motivation: A developmental study of children's reasons for liked an disliked behaviours." British Journal of Developmental Psychology no. 5:357-365.

Chirkov, V. R. Ryan, Y. Kim, and U. Kaplan. 2003. "Differentiating Autonomy From Individualism and Independence: A Self - Determination Theory Perspective on Internalisation of Cultural Orientations and Well-Being." Journal of Personality and Social Psychology no. 84 (1):97-110.

Dreze, J, and A. Sen. 1995. India: Economic Development and Social Opportunity: Oxford University Press.

Emirbabyer, M, and A. Mische. 1998. "What is Agency?" American Journal of Sociology no. 103:61.

Fernandez-Ballesteros, R, J. Diez-Nicolas, G. Vittorio Caprara and C. Barbaranelli, and A. Bandura. 2002. "Determinants and Structural Relation of Personal Efficacy to Collective Efficacy." Applied Psychology: An International Review no. 51 (1):18.

Fernando, S. 2014. Mental Health Worldwide: Culture, Globalization and Development. New York: Palgrave Mcmillan.

Foucault, M. 2007. Security, Territory, Population: Lectures at the Collège de France 1977-78. London: Palgrave Macmillan.

Gao, Z. 2012. "The emergence of modern psychology in China, 1876 - 1922." Annual Review of Critical Psychology no. 10:1-15.

Gecas, V. 1989. "The Social Psychology of Self-Efficacy." Annual Review of Sociology no. $15: 291-316$

Giddens, A. 1984. The constitution of Society: Outline of a theory of structuration: University of California Press.

Grabe, S. 2012. "An Empirical Examination of Women's Empowerment and Transformative Change in the Context of International Development." American Journal of Community Psychology no. 49 (1-2):233-245. doi: 10.1007/s10464-011-9453-y.

Hook, D. 2004. Critical Psychology: University of Cape Town Press.

Ibrahim, S. 2006. "From Individual to Collective Capabilities: The Capability Approach as a Conceptual Framework for Self-help." Journal of Human Development no. 7 (4):19. 
Ibrahim, S, and S. Alkire. 2007. "Empowerment and agency: A proposal for internationallycomparable indicators." Oxford Development Studies no. 35 (4).

Igarashi, Y. 2006. "Role of critical psychology in Japan: Protest against positivistic psychology and search for new knowledge of the mind." Annual Review of Critical Psychology no. 5:156-166.

Jackson, M. 1990. "The man who could turn into an elephant: Shape-shifting among the Kuranko of Sierra Leone." In Personhood and agency: the experience of self and other in African cultures, edited by Jackson Micheal and Karp Ivan, 59 - 78. Acta Univesitatis Upsaliensis.

Kabeer, N. 1999. "Resources, Agency, Achievements: Reflections on the Measurement of Women's Empowerment." Development and Change no. 30:435-464.

Kabeer, N. 2003. Gender Mainstreaming in Poverty Eradication and the Millennium Development Goals: A handbook for policy- makers and other stakeholders: Commonwealth Secretariat, the International development Research Council and the Canadian International Development Agency.

Klein, E. 2014. "Psychological Agency: Evidence from the Urban Fringe of Bamako." World Development no. 64 (C):642-653.

Klein, E. 2016. "Women's agency and the psychological domain: Evidence from the Urban Fringe of Bamako, Mali." Feminist Economics:1-24. doi: 10.1080/13545701.2015.1084867.

Lacan, J. 1977. "The Agency of the Letter in the Unconscious, or Reason Since Freud. ." In Écrits: a Selection., 146 - 178. Tavistock.

Lawrence, L. 1989. "A Concordance Correlation Coefficient to Evaluate Reproducibility." Biometrics no. 45 (1):255-268. doi: 10.2307/2532051.

Lin, L. 2000. "A note on the concordance correlation coefficient." Biometrics no. 56:324-325.

Long, N. 2001. Development sociology: Actor perspectives. London: Routledge.

Mansfield, N. 2000. Subjectivity: Theories of the self from Freud to Haraway: New York University Press.

Mkhize, N. 2004. "Summary." In Introduction to Critical Psychology, edited by Derek Hook, 24-52. Cape Town: University of Cape Town Press. 
Narayan, D, L. Pritchett, and S. Kapoor. 2009. Moving out of Poverty Volume 2: Success from the bottom up: Copublication of Palgrave Macmillan and the World Bank.

Nussbaum, M. 2001. Women and Human Development: The Capabilities Approach, Cambridge University Press. Cambridge.

Olney, M. and P Salomone. 1992. "Empowerment and choice in supported employment: Helping people to help themselves." Journal of Applied Rehabilitation Counselling no. 23 (3):41-44.

OPHI. March 2013 [date accessed]. Technical Notes on the Use of the Empowerment Module. edited by Oxford Poverty and Human Development Initiative. http://www.ophi.org.uk/wpcontent/uploads/Missing_Dimensions_Technical_Notes_Empowerment_Module.pdf?cda $\underline{6 \mathrm{c} 1 .}$

Riesman, P. 1990. "The Formation of Personality in Fulani Ethnopsychology." In Personhood and agency: the experience of self and other in African cultures, edited by Jackson Micheal and Karp Ivan, 169-190. Acta Univesitatis Upsaliensis.

Riesman, P. 1998. Freedom in Fulani Social Life: An Introspective Ethnography. University of Chicago Press.

Rose, N. 1999. Governing the Soul: The shaping of the Private Self. 2nd Edition ed. London: Free Association Books.

Rowlands, J. 1997. Questioning Empowerment: Working with Women in Honduras: Oxfam.

Ryan, R. 2012. Autonomy and Basic Psychological Needs and Wellbeing across Cultures: Research from Self-Determination Theory. Conference Paper Presentation Notes. In Does Wellbeing Travel Symposium. University of Bath.

Ryan, R. and E. Deci. 2000. "Self-Determination Theory and the Facilitation of Intrinsic Motivation, Social Development and Well-being." American Psychologist no. 55 (1).

Ryan, R. and E. Deci. 2006. "Self-regulation and the problem of human autonomy: Does psychology need choice, self-determination, and will?" Journal of Personality no. 74:1557-1586.

Sen, A. 1995. Inequality Reexamined. Oxford: Oxford University Press.

Sen, A. 1999. Development as freedom. Oxford: Oxford University Press. 
Sen, A, and J. Dreze. 2002. India: Development and Participation. Oxford: Oxford University Press.

Stewart, F. 2005. "Groups and Capabilities." Journal of Human Development no. 6 (2):21.

Stigler, J. R Schweder, and G. Herdt. 1990. Cultural Psychology: Essays on Comparative Human Development: Cambridge University Press.

Teo, T. 2015. "Critical Psychology: A geography of intellectual engagement and resistance."

American Psychologist no. 70 (3):243-254.

Wee, V, F Shaheed, S Choonara, M Jaschok, A Sim, and C Chiu. 2008. Women empowering themselves: A framework that interrogates and transforms. In The Research Programme Consortium on Women's Empowerment in Muslim Contexts, edited by University of Hong Kong.

${ }^{1}$ Writing about ka da I yèrè la and dusu is fraught. Nuance can be lost in translation where we have tried to articulate the inductive definitions of terms that have emerged in the research (by suggesting ka da I yèrè la and dusu may be understood as similar to self-belief and internal motivation). As this paper is written in English, a translation of the two concepts is required. Therefore, we are not claiming any absolute definition of ka da I yèrè la and dusu. Instead the descriptions used within the text only carve out a space in which the actual definition would be situated. Like a road sign, are pointing to a space to where one would find the absolute definition if desired. However, even if losing meaning in translation were not an issue, caution should be raised against the pursuit of absolute definitions. Following Lacan (1977), the quest to find an absolute definition would possibly be an infinite task as exact meanings of terms vary between people, and always will as language, like all structures, changes through time and space.

${ }^{2}$ Whilst JDS has a policy to allow third party access to data sets used in publications, this is not possible for this study. Unfortunately the ethics application granted for the original study does not allow for the data to be passed on to other parties.

${ }^{3}$ Female interviewee, The neighbourhood, $5^{\text {th }}$ January 2011.

${ }^{4}$ This coefficient takes values between 0 and 1 , with higher values denoting more concordance and 1 meaning full concordance. 